\title{
ГРЕЦИЗМИ И ЛАТИНИЗМИ У ВИНОГРАДАРСКОЈ ЛЕКСИЦИ
}

\begin{abstract}
У раду се разматра и анализира удео грецизама и латинизама у виноградарској лексици, прикупљеној на терену Војводине. Самом раду је претходила лексичко-семантичка анализа рађена према поставкама Н. И. Толстоја, односно према унеколико модификованој теорији семантичких микропоља (коју је дала Гордана Вуковић). Прикупљене лексеме разврстане су у 15 семантичких поља, а удео грецизама и латинизама анализиран је у оквиру сваког поља посебно.
\end{abstract}

Кључне речи: српски језик, дијалектологија, виноградарска лексика, грецизми, латинизми.

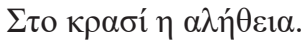

(У вину истина.)

In vino veritas.

(У вину је истина.)

\section{1. Увод}

Један од неколико основних процеса мењања, односно развоја лексикона једног језика јесте инфлусивни ток, где, поред осталих, спада и посуђивање, које Д. Шипка дефинише као „увођење екстерних елемената преко међукултурног лексичког трансфера у контакту са културама других језика“" (Шипка, 2006: 66). Да би се овај процес посуђивања могао разумети, треба имати у виду и друштвено-историјске околности, јер су извори посуђивања управо њима били условљени (Шипка, 2006:100). Међу позајмљеницама које су ушле у наш језик су и оне из грчког - грещизми и из латинског језика-латинизми.

Предмет досадашњих истраживања у лингвистичкој литератури били су посебно и грецизми: Грецизми у српском језику (в. Стојановић, 2003), Греиизми у српском језику: осврт на досадашња и поглед на будућа истраживања (в. Влајић-Поповић, 2009), Греичзми у српским народним говорима на територији Војводине (в. Влајић-Поповић, 2011), Грецизми у српском географском терминосистему (в. Ајџановић, 2017) и латинизми: Језики културна оријенатација унашој прошлости исадашњости (в. Ђорђић, 1932), Прилог испитивању предримских лексичких остатака у словеначком

\footnotetext{
${ }^{1}$ brankicama@gmail.com
} 
и српскохрватском језику (в. Скок, 1950) и О употреби латинизама у језику дневне штампе (в. Панић-Бабић, Љубишић, 2011). Поред ових, постоји и рад Интернационализми у српском руху (в. Мишеска Томић, 1996), где се говори о речима латинског и / или грчког порекла које су ушле у инвентар свих европских индоевропских језика, о тзв. интернационализмима, као и радови о лексици страног порекла уопште, где се могу наћи и грецизми и латинизми: Лексика покућства страног порекла у речнищима предвуковског периода (в. Ристић, 1996), Стране речи у икавском исказу (в. Миковић, 1996), Туђице у терминологији куће и покућства (в. Вуковић, 2000) итд.

У овом раду се разматра и анализира удео грецизама и латинизама у виноградарској лексици, забележеној на простору Војводине. Грађа је прикупљена на терену у разговору са информаторима (виноградарима) помоћу Упитника за бележење виноградарске лексике Института за српски језик САНУ. Самом раду претходила је лексичко-семантичка анализа прикупљене лексике, рађена према поставкама Н. И. Толстоја (в. Толстој, 1963; 1966), односно према унеколико модификованој теорији семантичких микропоља Гордане Вуковић (в. Вуковић, 1988). Прикупљена лексика разврстана је у 15 семантичких поља, а удео грецизама и латинизама анализиран је у оквиру сваког поља.

\section{2. Анализа корпуса}

У прикупљеном корпусу регистровано је 16 грецизама (калем, ластар, кондир, нектар, хлороза, перноспора, јагурине, ароматичан, цилиндар, каштар, буклија, бокал, литра, политра, подрум, колеба/колиба) и 18 латинизама (кобер, порталис, материја, густирати, култиватор, рафија, оидијум, конзумни, бачва, буре, дестилатор, рубин, ферментација, бирза, дестилацчија, проценат, град, деции). Поред њих, регистрована су и два тзв. хибрида, где је први део сложенице пореклом из латинског, а други део пореклом из грчког језика (ебулиоскоп, винометар).

Класификовано по семантичким пољима то се може представити табеларно на следећи начин:

\begin{tabular}{|l|l|l|l|}
\hline $\begin{array}{l}\text { НАЗИВ СЕМАНТИЧКОГ } \\
\text { ПОљА }\end{array}$ & ГРЕЦИЗМИ & ЛАТИНИЗМИ & ХИБРИДИ \\
\hline $\begin{array}{l}\text { 1. Типови земљишта за } \\
\text { угајање винове лозе }\end{array}$ & & & \\
\hline $\begin{array}{l}\text { 2. Биљка винова лоза и њени } \\
\text { делови }\end{array}$ & ластар, кондир & & \\
\hline
\end{tabular}




\begin{tabular}{|c|c|c|c|}
\hline $\begin{array}{l}\text { 3. Подлога, тј. различите } \\
\text { врсте лозе које служе као } \\
\text { подлога приликом калемљења } \\
\text { племенитијих сорти грожђа и } \\
\text { врсте калемљења }\end{array}$ & калем* & кобер, порталис & \\
\hline 4. Фазе у развоју винове лозе & нектар & & \\
\hline $\begin{array}{l}\text { 5. Радње у винограду и } \\
\text { машине и алатке које се } \\
\text { користе при обради винограда }\end{array}$ & & $\begin{array}{l}\text { материја, } \\
\text { густирати, } \\
\text { култиватор, } \\
\text { рафија }\end{array}$ & \\
\hline $\begin{array}{l}\text { 6. Болести и оштећења винове } \\
\text { лозе }\end{array}$ & $\begin{array}{l}\text { хлороза, } \\
\text { перноспора }\end{array}$ & оидијум & \\
\hline $\begin{array}{l}\text { 7. Плод винове лозе, његови } \\
\text { делови и типови }\end{array}$ & $\begin{array}{l}\text { јагурине, } \\
\text { ароматичан }\end{array}$ & конзумни & \\
\hline \multicolumn{4}{|l|}{ 8. Сорте винове лозе } \\
\hline $\begin{array}{l}\text { 9. Посуде, делови посуда } \\
\text { и справе за прераду воћа и } \\
\text { производњу вина и ракије }\end{array}$ & цилиндар & $\begin{array}{l}\text { бачва, буре, } \\
\text { дестилатор }\end{array}$ & \\
\hline $\begin{array}{l}\text { 10. Производи од грожђа и } \\
\text { другог воћа и њихове врсте }\end{array}$ & каштар & рубин & \\
\hline $\begin{array}{l}\text { 11. Радње у вези са } \\
\text { производњом и чувањем вина } \\
\text { и ракије }\end{array}$ & & $\begin{array}{l}\text { ферментација, } \\
\text { бирза, } \\
\text { дестилација }\end{array}$ & \\
\hline $\begin{array}{l}\text { 12. Инструменти за мерење } \\
\text { јачине вина и ракије и мерне } \\
\text { јединице }\end{array}$ & & проценат, град & $\begin{array}{l}\text { ебулиоскоп, } \\
\text { винометар }\end{array}$ \\
\hline 13. Судови за вино и ракију & $\begin{array}{l}\text { буклија, бокал } \\
\text { литра, политра }\end{array}$ & деци & \\
\hline $\begin{array}{l}\text { 14. Остава за вино и ракију, } \\
\text { пратећи елементи и други } \\
\text { објекти }\end{array}$ & $\begin{array}{l}\text { подрум, колеба/ } \\
\text { колиба }\end{array}$ & & \\
\hline $\begin{array}{l}\text { 15. Називи за вршиоце } \\
\text { појединих радњи }\end{array}$ & & & \\
\hline
\end{tabular}

Из табеле се може видети да у семантичким пољима 1, 8 и 15 нису регистровани ни грецизми ни латинизми. У највећем броју семантичких поља $(3,6,7,9,10$ и 13$)$ регистровани су и грецизми и латинизми. У семантичким пољима 2, 4 и 14 регистровани су само грецизми, а у семантичким пољима 5 и 11 само латинизми. Лексеме калем и бокал су подвучене и означене звездицом, јер се ради о индиректним грецизмима, односно о речима изворно грчког порекла, које су у наш језик ушле посредством неког другог језика - калем (преко турског) и бокал (преко италијанског). 
У друго семантичко поље сврстани су називи за биљку винову лозу и њене делове. Овде су регистрована два грецизма ластар ${ }^{2}$ и кондир. ${ }^{3}$ Лексема ластар јавља се у значењу ‘једногодишњи изданак лозе', док је кондир 'изданак лозе који има рода'.

У оквиру трећег семантичког поља нашли су се називи за подлогу, тј. за различите врсте лозе које служе као подлога приликом калемљења племенитијих сорти лозе и називи за врсте калемљења. У овом семантичком пољу регистрован је један грецизам (индиректни) калем ${ }^{4}$ и два латинизма кобер ${ }^{5}$ и порталис. Лексема калем јавља се у значењу 'лоза која је настала калемљењем'. Од ње су даље изведени глагол несвр. вида калемити и глаголи свр. вида накалемити, прекалемиmи у значењу 'поново (на)калемити лозу', затим глаголска именица калемљење, као општи назив за радњу калемљења и именица калемар, која се јавља у различитим творбеним ликовима калемарка, калемача, калемачица, којима се означава нож за калемљење. Другим двема лексемама (кобер, порталис) означавају се врсте дивље подлоге на коју се калеми питома сорта. Ово су страни називи који се користе као стручни термини у виноградарству. Лексема кобер у истом облику регистрована је на ширем подручју (у Александровачкој жупи и Братишковцима у Далмацији), тако да се не може везивати за неки посебан крај, нити сматрати особеношћу само једног виноградарског региона. Овде треба напоменути да се у ранијем периоду, до пре 150 година, винова лоза у свету гајила на сопственом корену. Међутим, када се у Европи појавила филоксера, тј. сушибуба, дошло је до наглог пропадања винограда и то на великим површинама и једини начин да се они спасу био је у калемљењу племените лозе на отпорне лозне подлоге, јер је од ње (од лозне подлоге) зависило какав ће бити развој, принос и квалитет грожђа, а пре свега каква ће бити отпорност и колика ће бити дуговечност сорте која је на њу накалемљена (Куљанчић, 2007: 167).

Четврто семантичко поље окупља називе за фазе у развоју винове лозе и у оквиру њега забележен је један грецизам нектар. ${ }^{6}$ Овом лексемом означава се 'сок који лоза пушта уочи вегетације.'

\footnotetext{
${ }^{2}$ Именица грчког порекла која је у нашем језику у употреби од XVI века (РЈАЗУ, 1898-

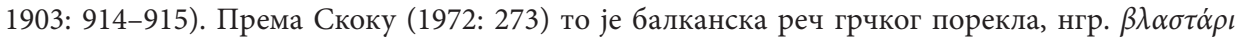
(деминутив од $\beta \lambda \alpha \sigma \tau o ́ \varsigma)$. Ушла је у балканске језике преко манастирског виноградарства и вртларства. На западу је непозната.

${ }^{3}$ Именица грчког порекла (РЈАЗУ, 1898-1903: 265-266), мада се у речницима страних речи среће и у другом значењу. Од гр. kántharos - трбушаста чаша, врч, крчаг, пехар; исто и дијал. кондијер (уп. Клаић, 1979: 721).

${ }^{4}$ Tur. kalem od ar. qaläm od grč. kálamos (уп. Клајн, Шипка, 2006: 568). И према Шкаљићу (1979: 387) то је грецизам добијен преко турског (калем/ калам < тур. kalem < ap. qaläm < гр. kálamos. J. Влајић-Поповић овај грецизам сврстава у индиректне, односно у турске грецизме (изворно грчке речи, које су позајмљене из турског језика) (уп. Влајић-Поповић, 2009: 391).

${ }^{5}$ Од лат. coopertus (уп. Богдановић, Вељковић, 2001: 79).

${ }^{6}$ Од гр. néktar - ...; 2. сладак сок који излучују биљке... (уп. Клаић, 1979: 934).
} 
У пето семантичко поље сврстани су називи за радње у винограду и машине и алатке које се користе при обради винограда. Овде су регистровани само латинизми - материја, ${ }^{7}$ густирати ${ }^{8}$, култиватор ${ }^{9}$ и рафија. ${ }^{10}$ Лексемом материја означава се 'смеша течности за прскање лозе'. Глагол густирати јавља се у значењу ‘чупати назрела зрна грозда док је на лози', док се лексемом култиватор именује 'машина која служи за обраду земље на којој су лозе'. Рафија је средство (врпца) које се користи за повезивање лозе у пролеће.

У оквиру шестог семантичког поља нашли су се називи за болести и оштећења винове лозе. Забележена су два грецизма - хлороза ${ }^{11}$ и перноспо$p a^{12}$ и један латинизам - оидијум. ${ }^{13}$ Све три лексеме означавају 'болест лозиног листа од које вене или се суши’. Оидијум је болест винове лозе у народу познатија као пепелница, а перноспора је у ствари пламењача.

Седмо семантичко поље окупља називе за плод винове лозе, његове делове и типове. У овом семантичком пољу регистрована су два грецизма - јагурине ${ }^{14}$ и ароматичан ${ }^{15}$ и један латинизам - конзумни. ${ }^{16}$ Лексемом јагурине означава се грожђе које накнадно израсте (познатије као греш, грешеви), док се придев ароматичан јавља у оквиру ви-

\footnotetext{
${ }^{7}$ Од лат. materia (уп. Клаић, 1979: 856).

${ }^{8}$ Од лат. gustare - кушати, окушати јело; налазити задовољство, уживати у посматрању некога или нечега (јела/ одела)... (уп. Вујаклија, 2006: 186). Б. Клаић (уп. 1979: 507) код глагола гусии иайи - 1. кушати, 2. уживати у јелу или у проматрању нечега, наслађивати се... упућује на густи од лат. gustus - 1. укус, тек, мерак, задовољство, ужитак, прохтев, ћуд, ћеф, хир.

${ }^{9}$ Од нвлат. cultivator - свака пољопривредна справа за површинску обраду земљишта, плуг, дрљача, (која одстрањује коров и тиме оплемењује земљу) (уп. Вујаклија, 2006: 469).

${ }^{10}$ Од мадаг.; лат. Raphia ruffia - лико једне афричке палме; служи за повезивање у воћарству, за плетење кошара и сл. (уп. Клаић, 1979: 1127).
}

${ }^{11}$ Од гр. chlorós - отворенозелен, зеленожут - ...; 2. бот. болест биљака при којој лишће губи зеленило (хлорофил) и постаје жуто (хлоротично) (уп. Вујаклија, 2006: 989).

${ }^{12}$ Према Скоку (1972: 642) peronospora $\mathrm{f}=$ prònospora $($ Potomje) то је виноградарски термин 19. в. за болест на винској лози, код нас опажена 1890. а у Италији 1879. године. Он истиче да је то учена грчка сложеница од $\pi \varepsilon \rho \alpha ́ \omega$ 'бушим' и олора́ 'семе'.

${ }^{13}$ Од лат. oidium - болест винове лозе (врло ситне гљивице, иееиелина, иееиелница, маћа, сијер) (уп. Клаић, 1979: 966).

${ }^{14}$ Ова лексема забележена је и у Александровачкој жупи у облику јагуурида и аутори наводе да је то балканска реч грчког порекла (уп. Богдановић, Вељковић, 2001: 77). Такође, Ј. ВлајићПоповић у свом раду (уп. Влајић-Поповић, 2009: 389), класификујући грецизме хронолошки на старовековне, средњовековне, нововековне и модерне, бележи облик јаг̈урида и сврстава га у нововековне грецизме (то су савремене књижевне и дијалекатске речи, често су то балкански грецизми, заједнички свим или бар већини балканских језика).

${ }^{15}$ Од грч. aróma - мирођија, мирисаве траве, - 1. мирис; нарочито угодан мирис...; прид. аромайичан - мирисан, угодна мириса, миомирисан (уп. Клаић, 1979: 102).

${ }^{16}$ Од лат. consumere - 1. (по)трошити, 2. (по)јести, (по)пити... (уп. Клајн, Шипка, 2006: 643). 
шечлане лексеме ароматична грожђа, која представља општи назив за мирисна грожђа. Придев конзумни исто је део вишечлане лексеме конзумно грожђе којом се именује семема 'општи назив за грожђе које служи само за јело'.

У девето семантичко поље сврстани су називи за посуде, делове посуда и справе за прераду воћа и њихове врсте. Овде су забележени један грецизам - излиндар ${ }^{17}$ и три латинизма бачва, ${ }^{18}$ буре ${ }^{19}$ и дестилатор. ${ }^{20}$ Лексеме циилиндар и дестилатор означавају део казана, односно хладњак при дестилацији ракије. Лексема бачва јавља се у два значења 'изузетно велико буре (преко 1000 л)' и 'буре које стоји водоравно-положено', док се за репрезентовање семема 'посуда у коју сви берачи стављају грожђе', 'дрвена посуда у којој се држи ракија' и 'буре које стоји водоравно-положено’користи лексема буре.

Десетим семантичким пољем обухваћени су називи за производе од грожђа и другог воћа и њихове врсте. У оквиру овог семантичког поља забележени су један грецизам - каштар ${ }^{21}$ и један латинизам рубин. ${ }^{22}$ Прва лексема јавља се у облику каштро (вино), а означава 'реско, опоро вино'. Другом лексемом означава се 'вино загасито црвене боје'

У оквиру једанаестог семантичког поља нашли су се називи за радње у вези са производњом и чувањем вина и ракије. У овом сематичком пољу

\footnotetext{
${ }^{17}$ Од грч. kýlindros (уп. Вујаклија, 2006: 1005).

${ }^{18}$ Од влат. buttia, од buttis (уп. Скок, 1971: 86). М. Влајинац наводи да је бачва по мишљењу Ђуре Даничића постала од сред. лат. bacchus, односно bacuum = каца, када и да је у јужним и југоисточним крајевима позната и под називима бочва и б’чва. Даље каже, да „код већине нашег народа важи као велики подрумски дрвени суд за вино и друга пића, који се помиње почевши још од 13. века и без којег се ни данас не може замислити ниједан већи подрум за пића“ (уп. Влајинац, 1964: 153).

${ }^{19}$ Према РСЈ (2011: 116) буре лат. - обао, већи суд, обично дрвен (састављен од дуга причвршћених обручима) испупчених бокова и са два дна, за држање течности или бакалске робе (брашна, соли, пекмеза и др.). Од сред. лат. bareta и фр. burette... „тако се назива уопште сваки дрвени подрумски суд, састављен од дуга, више или мање бокастог облика, и учвршћен обручима, затворен на обе стране данцима“" (уп. Влајинац, 1964: 174). У нашим јужним и југоисточним крајевима назива се бачва или бочва, у западним крајевима употребљава се назив барило, док се на Косову и Метохији јавља облик бурило, према турском фучија (уп. Влајинац, 1964: 174).

${ }^{20}$ Од лат. destillare - капати, 1. апарат за дестилацију, 2. човек који врши дестилацију (уп. Клаић, 1979: 284-285).

${ }^{21}$ Од грч. késtra - šilo, - опор, оштар (уп. Клаић, 1979: 673).

${ }^{22}$ Од срлат. rubinus (lapis) - црвени камен... (уп. Клајн, Шипка, 2006: 1089).
} 
регистровани су само латинизми - ферментащчија, ${ }^{23}$ бирза ${ }^{24}$ и дестилащчја. ${ }^{25}$ Лексемом ферментација означава се радња врења садржаја који је измуљан. Бирза је скрамица која се јавља на површини вина, док се лексемом дестилација означава процес добијања ракије.

Дванаесто семантичко поље окупља називе за инструменте за мерење јачине вина и ракије и мерне јединице. И овде су регистрована два латинизма - проченат ${ }^{26}$ и град ${ }^{27}$ и два тзв. хибрида (где је први део сложенице пореклом из латинског, а други део пореклом из грчког језика) ебулиоскоп ${ }^{28}$ и винометар. ${ }^{29}$ Овим двема лексема означава се инструмент за мерење јачине вина. Лексема проценат означава мерну јединицу за јачину вина, поред много чешће лексеме малиган, док се лексема град јавља у два значења - као ‘инструмент за мерење јачине ракије' и 'подељак на инструменту за мерење јачине ракије'.

У тринаесто семантичко поље сврстани су називи за судове за вино и ракију. Овде су забележени грецизми буклија, ${ }^{30}$ бокал, ${ }^{31}$ литра, ${ }^{32}$ политра

${ }^{23}$ Од лат. fermentatio - процес који настаје деловањем фермента; врење, превирање, ускишњавање (уп. Клајн, Шипка, 2006: 1315).

${ }^{24}$ Од лат. birsa - кожа, 1. превлака, павлака понад (поквареног) вина, винска плесањ, 2. со винске киселине... (уп. Клаић, 1979: 176).

${ }^{25}$ Од лат. destilattio - хем. процес пречишћавања путем загревања; испаравање течности и поновно згушњавање у течност; испаравање, печење ракије... (уп. Вујаклија, 2006: 207).

${ }^{26}$ Од лат. pro centum - 1. постотак, стоти део неке количине или броја... (уп. Клаић, 1979: 1092).

${ }^{27}$ Од лат. gradus - ...; 3. условна јединица за мерење густине течности, концентрације раствора или садржаја алкохола, степен. (уп. Клајн, Шипка 2006: 302).

${ }^{28}$ Од лат. ebullire - избијати кључајући и грч. skopéo - гледам - хем. инструмент за мерење тачке кључања ради одређивања садржине алкохола...; 2. апарат за брзо одређивање количине алкохола у вину... (уп. Вујаклија, 2006: 245).

${ }^{29}$ Од лат. vinum - вино и грч. métron - справа за мерење јачине вина, виномер (уп. Вујаклија, 2006: 152).

${ }^{30}$ Од новгрч. bōkalion - чутура, плоска (уп. Клаић, 1979: 811).

${ }^{31}$ J. Кашић наводи (1971: 171) да је бокал реч грчког порекла, која је нама дошла вероватно преко талијанског. То потврђују и речници страних речи. Код Клаића (уп. 1979: 184) бокал тал. boccale, од новогр. bokalion - крчаг, пехар, врч. И Клајн, Шипка исто наводе (уп. 2006: 222) да је бокал - итал. boccale, од гр. baukális - повећи, обично обао суд са дршком, за воду, вино или неко друго пиће, садржина таквог суда, количина која стане у бокал.

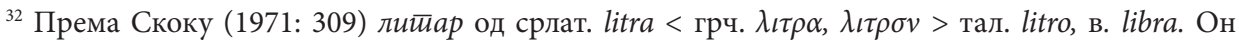
наводи да је грецизам балкански: буг. litra, арб. litrë. М. Влајинац наводи (1968:536) да лийра - грч. $\lambda \iota \tau \rho \alpha$, одговара лат. libra и тал. libbra, нем. Pfund или нашој фуниии. „Истиче се као једна од најстаријих јавно признатих мера за иежину, па у вези с тим донекле и за зайремину, коју је наш народ при досељењу затекао, примио и, може се рећи, до данас сачувао у употреби за мерење тежине свих врста производа, како сувих тако и течних“ (Влајинац, 1968: 536). Даље каже да је литира као назив унета у наше крајеве из Византије, много пре доласка Турака, што потврђују подаци још из $\mathrm{V}$ века, који говоре о томе да су се у Византији плате чиновника и 


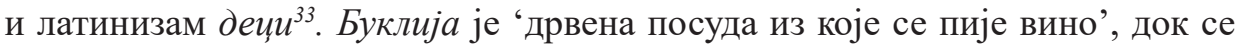
лексема бокал јавља у два значења ‘стаклена посуда за вино’ и 'стаклена посуда за ракију запремине више од 2 л'. Лексеме литра и политра исто су регистроване у два значења 'стаклена посуда за вино’ и 'стаклена посуда за ракију запремине до 2 литра'. Деци је 'бочица за ракију'.

И на крају, у четрнаестом семантичком пољу, где су окупљени називи за оставу за вино и ракију, пратеће елементе и друге објекте регистрована су два грецизма подрум ${ }^{34}$ и колеба/ колиба. ${ }^{35}$ Лексема подрум забележена је у значењу 'остава за вино и ракију', док колеба са фонетским ликом колиба означава кућицу у винограду. ${ }^{36}$

\section{3. Закључне напомене}

На основу анализе могу се извести следећи закључци:

1. Удео грецизама и латинизама у виноградарској лексици забележеној на терену Војводине није велик, али није ни занемарљив.

2. У виноградарској лексици забележеној на терену Војводине регистрован је нешто већи број латинизама (18) од грецизама (16).

3. У три семантичка поља (1.Типови земљишта за узгајање винове лозе, 8. Сорте винове лозе и 15. Називи за вршиоце појединих радњи) нису регистровани ни грецизми ни латинизми.

4. Грецизми су заступљенији у оним семантичким пољима којима се именују биљка винова лоза и њени делови, затим фазе у развоју винове лозе и остава за вино и ракију, пратећи елементи и други објекти, док је већа

војничких старешина одређивале у литрама злата...(уп. Влајинац, 1968: 536).

${ }^{33}$ Према Клаићу деци $u^{1}$ - лат. (исп. decem) - у сложеницама префикс који означава десети део нечега, посебно у метричком систему мера,; деци ${ }^{2}$ - скраћено од децилитар... (уп. Клаић, 1979: 263).

${ }^{34}$ Од грч. hypo - испод, drómos - цеста, пут, 1. подземна просторија (обично испод куће); 2. винара, коноба, крчма, таверна, пивница... (уп. Клаић, 1979: 1060).

35 Према Скоку (1972: 124) колеба - ... Румуни су посудили colibă. Карпатски рум. пастири пренели су ту балканску реч у чешки и пољски. Нгрч. kalivi, apб. kolubë, kalive < стгрч. $\chi \alpha \lambda \dot{\beta} \beta \eta$, од $\chi \alpha \lambda v \pi \tau \omega$, тур. kalive, поред kaliba и koliba. Он наводи да је то балканска реч грчког порекла... Према Фасмеру то је посуђеница из старијег периода грчког језика као korab. J. Влајић-Поповић (2009: 388) овај грецизам (уз још неколицину) исто сврстава у старовековне, општесловенске, наводећи да су они још од претписменог доба сачувани до данас у књижевном језику.

${ }^{36}$ Поред ове лексеме, у овом значењу регистроване су и лексеме кућа, кућица и виноградарска и йударска кућица. Информатори су навели да су се колибе правиле од трске (пре тридесет, четрдесет година) и да се данас ретко могу наћи, док су виног̈радарска и йударска кућица биле зидане. 
заступљеност латинизама регистрована у оним семантичким пољима у које су сврстани називи за радње у винограду и машине и алатке које се користе при обради винограда, потом радње у вези са производњом и чувањем вина и ракије и називи за инструменте за мерење јачине вина и ракије и мерне јединице.

\section{Литература}

Ајџановић, 2017: М. Ајџановић, Грецизми у српском географском терминосистему, Словенска терминологија данас/ уредници Предраг Пипер, Владан Јовановић, Београд: САНУ, Институт за српски језик САНУ, 509-519.

Богдановић, Вељковић, 2001: Н. Богдановић, Д. Вељковић, Жупски виноградарски речник, Александровац: Скупштина општине Александровац, Музеј винарства и виноградарства.

Влајинац, 1961: М. Влајинац, Речник наших старих мера - у току векова, І свеска, (Посебна издања САНУ, књ. CCCXLIX, Одељење друштвених наука, књ. 40), Београд: Издавачка установа „Научно дело“.

Влајинац, 1964: М. Влајинац, Речник наших старих мера - у току векова, II свеска, (Посебна издања САНУ, књ. CCCLXXII, Одељење друштвених наука, књ. 47), Београд: Издавачка установа „Научно дело“.

Влајинац, 1968: М. Влајинац, Речник наших старих мера - у току векова, III свеска, (Посебна издања САНУ, књ. CDXVIII, Одељење друштвених наука, књ. 63), Београд: Издавачка установа „Научно дело“.

Влајић-Поповић, 2009: Ј. Влајић-Поповић, Грецизми у српском језику: осврт на досадашња и поглед на будућа истраживања, Београд: Јужнословенски филолог, LXV, 375-403.

Влајић-Поповић, 2011: Ј. Влајић-Поповић, Грецизми у српским народним говорима на територији Војводине, Београд: Јужнословенски филолог, LXVII, $197-215$.

Вујаклија, 2006: М. Вујаклија, Лексикон страних речи и израза, Београд: Просвета.

Вуковић, 1988: Г. Вуковић, Терминологија куће и покућства у Војводини, Нови Сад: Филозофски факултет.

Вуковић, 2000: Г. Вуковић, Туђице у терминологији куће и покућства, Нови Сад: Зборник Матице српске за филологију и лингвистику, XLIII, 125-136.

Ђорђић, 1932: П. Ђорђић, Језик и културна оријентација у нашој прошлости и садашњости, Богословље: орган Православног богословског факултета у Београду, 7, 3, 215-230.

Кашић, 1971: Ј. Кашић, Виноградарска лексика у Срему, Нови Сад: Годишњак Филозофског факултета у Новом Саду, књ. XIV/1, 159-180.

Клаић, 1979: В. Klaić, Rječnik stranih riječi, Zagreb: Nakladni zavod Matice hrvatske. 
Клајн, Шипка, 2006: И. Клајн, М. Шипка, Велики речник страних речи и израза, Нови Сад: Прометеј.

Куљанчић, 2007: И. Куљанчић, Виноградарство: винова лоза, та божанска биљка, Нови Сад: Прометеј.

Миковић, 1996: M. Miković, Strane reči u ikavskom iskazu, О лексичким позајмљеницама: зборник радова са научног скупа Стране речи и изрази у српском језику, са освртом на исти проблем у језицима националних мањина (Градска библиотека, Суботица, 18-20. октобар 1995)/ главни уредник: Јудита Планкош, Суботица: Градска библиотека - Београд: Институт за српски језик САНУ, 241-252.

Мишеска Томић, 1996: О. Мишеска Томић, Интернационализми у српском руху, О лексичким позајмљеницама: зборник радова са научног скупа Стране речи и изрази у српском језику, са освртом на исти проблем у језицима националних мањина (Градска библиотека, Суботица, 18-20. октобар 1995)/ главни уредник: Јудита Планкош, Суботица: Градска библиотека - Београд: Институт за српски језик САНУ, 69-80.

Панић-Бабић, Љубишић, 2011: B. Panić-Babić, S. M. Ljubišić, O upotrebi latinizama u jeziku dnevne štampe, Наука и политика: зборник радова са Научног скупа Пале, 22-23. мај 2011, 231-236.

Ристић, 1996: С. Ристић, Лексика покућства страног порекла у речницима предвуковског периода, О лексичким позајмљенииама: зборник радова са научног скупа Стране речи и изрази у српском језику, са освртом на исти проблем у језицима националних мањина (Градска библиотека, Суботица, 18-20. октобар 1995)/ главни уредник: Јудита Планкош, Суботица: Градска библиотека - Београд: Институт за српски језик САНУ, 253-268.

PJA3У: Rječnik hrvatskoga ili srpskoga jezika, dio V, Zagreb: JAZU, 1898-1903.

PCJ: Речник српскога језика/ [израдили Милица Вујанић и др.; редиговао и уредио Мирослав Николић], измењено и поправљено издање, Нови Сад: Матица српска, 2011.

Скок, 1971: P. Skok, Etimologijski rječnik hrvatskoga ili srpskoga jezika, knj. I (A - J), Zagreb: JAZU.

Скок, 1972: P. Skok, Etimologijski rječnik hrvatskoga ili srpskoga jezika, knj. II (k poni ${ }^{1}$ ), Zagreb: JAZU.

Скок, 1973: P. Skok, Etimologijski rječnik hrvatskoga ili srpskoga jezika, knj. III (poni²-Ž), Zagreb: JAZU.

Скок, 1974: P. Skok, Etimologijski rječnik hrvatskoga ili srpskoga jezika, knj. IV (kazala), Zagreb: JAZU.

Скок, 1950: P. Skok, Prilog ispitivanju predrimskih leksičkih ostataka u slovenačkom i srpskohrvatskom jeziku, Slavistična revija, god.3, 350-355.

Стојановић, 2003: М. Стојановић, Грецизми у српском језику, Даница: српски народни илустровани календар за годину, год. 10, 323-330.

Толстој, 1963: Н. И. Толстой, Из опытов типологического исследования славян- 
ского словарного состава I. Вопросы языкознания 1, Москва, 29-45.

Толстој, 1966: Н. И. Толстой, Из опытов типологического исследования

славянского словарного состава II. Вопросы языкознания 5, Москва, 16-36.

Урукало, 1982: M. Urukalo, Vinogradarska leksika Bratiškovaca, Нови Сад: Прилози проучавағу језика, бр. 18, 155-183.

Шипка, 2006: D. Šipka, Osnovi leksikologije i srodnih disciplina, Novi Sad: Matica srpska.

Шкаљић, 1979: A. Škaljić, Turcizmi u srpskohrvatskom jeziku, Sarajevo: „Svjetlost“, OOUR, izdavačka djelatnost.

Brankica Đ. Marković

\section{GREEC AND LATIN LOANWORDS IN VINICULTURAL LEXIS}

\section{Summary}

The paper analyzes the share of Greek and Latin loanwords in vinicultural lexis, based on material compiled in the region of Vojvodina. The paper was preceded by lexical-semantical analysis of the compiled lexis in accordance with the postulates of N. I. Tolstoy, i. e. the somewhat modified theory of semantic microfields (presented by Gordana Vukovic). The compiled lexemes were categorized into 15 semantic fields, whereas the share of Greek and Latin loanwords was analyzed separately in every category.

Key words: Serbian language, dialectology, vinicultural lexis, Greek and Latin loanwords. 